\title{
Salary Negotiation Patterns between Women and Men in Academic Libraries
}

\section{Elise Silva and Quinn Galbraith}

\begin{abstract}
Due to persistent wage gaps between men and women nationally, and in the field of academic librarianship, researchers wished to study possible issues that contribute to the phenomenon. This study examines the tendency for men and women to negotiate salaries in academic libraries upon hire. Researchers surveyed professional librarians employed in ARL (Association of Research Libraries) member institutions and found that women were statistically less likely than their male counterparts to engage in salary negotiations; and, when they did negotiate, they were less successful than men. This finding changed when a woman attained a high management status: female heads, deans, and directors were more likely to negotiate than female librarians in nonadministrative positions were. Researchers also found that the longer an individual (either male or female) worked in the field of academic librarianship, the more likely that individual would be to negotiate for higher salary upon hire.
\end{abstract}

\section{Introduction}

Historically known as "one of the earliest professions to be open to women," ${ }^{1}$ librarianship has long been associated with females. Yet, according to Library Trends, women "still have not achieved parity" in Association of Research Library (ARL) member institutions, even though more women do continue to enter the administrative ranks of the profession. ${ }^{2}$ For example, in 2011, men still held 40 percent of library head, dean, and director positions, while men made up only 17 percent of total positions in academic libraries. ${ }^{3}$ Though representation is one form of parity, equal pay for equal work is another. In national discussions, salary negotiation and wage discrepancy trends are well studied, particularly from a gender perspective. ${ }^{4}$ Such trends are of particular interest in academic libraries, as evidenced by the yearly ARL salary survey, which studies equity within the profession. This yearly survey continually finds "that salaries for women in US ARL university libraries have not yet met parity with that of men. In 2014-2015 the overall salary for women was 95.7\% of that of men," a figure that had regressed from the year previous. ${ }^{5}$ Surprisingly little research has gone into explaining

Elise Silva is the University Writing Librarian and Quinn Galbraith is the Sociology and Family Life Librarian in the Harold B. Lee Library at Brigham Young University; e-mail: elise_silva@byu.edu, quinn galbraith@byu.edu. A special thanks to research assistants Mathew Madsen, BYU, and Jessica Mansfield, BYU. (C2018 Elise Silva and Quinn Galbraith, Attribution-NonCommercial (http://creativecommons.org/ licenses/by-nc/4.0/) CC BY-NC. 
this reality. For instance, some scholarly literature about the issue in academic libraries considers salary satisfaction rates ${ }^{6}$ but many of these are smaller case studies that are university-specific. ${ }^{7}$ Furthermore, many of these studies are outdated.

Given the evidence that women are paid less than men in academic libraries (and indeed, in academia in general), ${ }^{8}$ the authors of this study sought to further scrutinize why full parity has not yet been met by studying male and female salary negotiation patterns - a potential factor in the gender pay gap. The authors created an extensive survey with a large sample group that would reflect salary negotiation trends in academic libraries by giving specific attention to gendered aspects. By doing this, the authors hoped to shed some light on how negotiation patterns lead to gendered salary discrepancies. Striving to understand the nuances of the gender pay gap is even more important when taken in the context of other recent studies from female-dominated professions, which show that, even in jobs like nursing, men still make more than women "across settings, specialties, and positions with no narrowing of the pay gap over time." ${ }^{\prime 9}$ Librarians, and other professionals alike, must understand the nuanced underpinnings of the pay gap to move toward a more equitable future.

Due to popular conceptions that women engage in negotiations at a lower rate than their male counterparts, the authors in this study hypothesized that the same would be true in academic libraries. The authors further hypothesized that women would be less successful in their negotiations for higher pay than men were in academic libraries (findings that would help to explain the overall gendered wage gap in the profession). Surprisingly, in initial analyses, the differences between men and women negotiating in academic libraries was not statistically significant; however, when the authors separated out library heads, directors, and deans from librarians, the results were statistically significant. Female deans and directors were much more likely to negotiate than female librarians were (though not statistically more likely to negotiate than male deans and directors). In addition, female librarians were significantly less likely to negotiate than male librarians were; and, when they did negotiate, they received less from their negotiations than male librarians did. Related to these findings was the conclusion that the likelihood of an individual negotiating grew with the number of years that individual spent working in the field - an unsurprising finding if one assumes the longer an individual works, the more leverage that individual has to negotiate for a higher salary.

As the literature review will enumerate, many issues are at play in whether an individual chooses to negotiate. Recent research, for example, shows that moral identities could play a role in the gendered disparities in negotiation practices, ${ }^{10}$ as can the socialized, and increasingly complex, differences between men and women and their competitive tendencies. This is not to say that women are less competitive than men are; instead, it demonstrates that they understand the social ramifications of vocalizing such competitive leanings. Indeed, "women are not rewarded or encouraged to be competitive at work or more generally in society." 11

The negotiation process itself can be complicated as well, with major salary negotiations taking place at the time of hire, but other negotiations (like working flexibly) taking place once a worker has been employed for some time. This study focuses on salary negotiations that take place at the time of hire, a practice that, if it has different initial monetary outcomes for men and women in terms of starting salary, can lead to a compounded pay gap difference between men and women later in their careers.

\section{A Brief Literature Review: Negotiation Practices}

Well-cited studies, like the ones referenced in Linda Babcock and Sara Laschever's book Women Don't Ask: Negotiation and the Gender Divide, suggest that women do not negoti- 
ate as often as men do. Babcock and Laschever report on a study assessing students graduating from Canregie Mellon University with master's degrees: “only 7 percent of the female students had negotiated but 57 percent (eight times as many) of the men had asked for more money."12 Babcock and Laschever further find that negotiations helped students (mostly men) "increase their starting salaries by 7.4 percent on average, or $\$ 4083$ - almost exactly the difference between men's and women's average starting pay... [suggesting that] differences between the men and the women might have been eliminated if the women had negotiated their offers." ${ }^{13}$ This is contested, though, as other studies show women having lower monetary negotiation goals than men do and "although men and women appeared equally confident, men's confidence was associated with significantly higher aspiration levels." ${ }^{14}$ In contrast with Babcock and Laschever's assumption that, if women negotiate, they may be able to make up the difference in the gender wage gap, research shows that when women do negotiate, they "obtain lower monetary returns from negotiation" 15 in comparison to men. One study showed that men average 4.3 percent more after negotiating than their initial offer, whereas women average only 2.7 percent more. ${ }^{16}$

There are many reasons for this gendered negotiation disparity. The first may be fear of backlash for women stepping out of stereotypically feminine roles into an assertive role while bargaining. One study found that individuals, upon reading job interview transcripts, perceived female candidates as more demanding and less "nice" than male candidates were perceived to be, even when both males and females were engaged in similar behaviors. ${ }^{17}$ In this sense, a woman might anticipate social or (even financial) backlash from her stepping out of gender expectations and choose not to negotiate to avoid such a consequence. Other studies corroborate this by showing that women are thoughtful about when they negotiate and carefully weigh the potential risk of appearing too forward. In other words, women know when to ask, because they are keenly aware of social expectations and consequences of asking. ${ }^{18}$

Another reason women may negotiate less often than men is that females tend to be more risk averse than males and have different "ethical playbooks." ${ }^{19}$ In a study conducted that compared men and women as they played ultimatum games, researchers found that men were more optimistic about their potential success in the game than women were, taking more risks, exhibiting less caution, and acting more aggressively. ${ }^{20}$ This may relate to findings discussed above, which show that, even when women do negotiate, they are more conservative in their approach than males tend to be.

As Jessica Kennedy and Laura Kray argue, the barriers that keep women from negotiating can be split up into three categories: cognitive, motivational, and paradigmatic. Cognitive barriers result from negative stereotypes revolving around women who choose to negotiate (as already discussed in this literature review). Motivational barriers stem from the societal perception that, even when women do negotiate, their negotiation skills are lacking - thus leading to an outcome where women do not fare well in negotiations because they are not expected to fare well by their negotiation counterpart. Paradigmatic barriers include research-based studies, which may be conducted in ways that exaggerate the gender differences based on their methodological assumptions. Such studies and the views they portray can actively work against women's best interests. ${ }^{21}$

Given this final point by Kennedy and Kray, which argues that flawed studies might be partly to blame for perpetuating the stereotype of the undernegotiating female job candidate, a growing body of literature suggests that, under certain circumstances, women will negotiate as often as men. For instance, the sex of the person with whom the job candidate is negotiating may play a role in gendered negotiation behavior, with studies finding that both men and women are less likely to attempt bargaining when 
their negotiation counterpart is female. ${ }^{22}$ Another factor that influences the likelihood of women negotiating is the job listing itself. When job offers and job discussions explicitly state that wage is negotiable, men and women negotiate at similar rates; but, when the job listing's language is ambiguous, men perform better than women do at negotiations. ${ }^{23}$ Finally, recent research shows that, for both men and women, when the goal of negotiation is framed altruistically, or as a social benefit, individuals are more prone to negotiate. ${ }^{24}$

Furthermore, status matters. When a woman was perceived as having a higher status than the average candidate (whether it be by education, title, rank, or other factors such as previous leadership experience), she was more likely to have a successful negotiation experience than a woman without these external status factors. ${ }^{25}$ This discussion of power is an important one, as some researchers conclude that differences in salary negotiation are less about gender and more about power itself. Mary Hogue, Janice D. Yoder, and Steven B. Singleton argue that this "seemingly gender-related difference more accurately is a status-related difference," where men internalize their higher social position and women internalize their lower social positions at the bargaining table. ${ }^{26}$

Similarly, literature does corroborate that experience plays a crucial role in salary negotiations, meaning that, the more work experience an individual has, the more likely that individual is to negotiate ${ }^{27}$ (perhaps because the more jobs one has held, the more negotiation experience one has had in the past). Other studies show that individuals having negotiation experience or training - something that an individual who has worked for longer would ostensibly have-negotiate more often and better than those who do not have this background. In other words, "Much of the improvement in integrative negotiation performance in an unchanging environment can be accounted for by experience." 28

\section{Methodology and Limitations}

In the summer of 2015, researchers e-mailed directors of 110 English-speaking academic libraries that were members of the Association of Research Libraries (ARL) and invited them to participate in an IRB-approved survey that would measure variables that might explain gender salary differences. The survey was designed by a team of academic librarians and research assistants after a thorough review of the literature surrounding gender and racial pay gaps in libraries. Researchers explained to library contacts that the survey was written with the primary purpose of further understanding the gender and racial wage gaps in ARL libraries. Only variables related to negotiation and gender are reported on in this article, though the wider study included questions related to race and ethnicity as well. To garner participation, each library was incentivized by offering a custom report of the data, comparing their school's responses to the collective results of the survey. Forty-four of the 110 contacted libraries agreed to participate, putting the organizational participation rate around 40 percent.

To control for employment-related differences within the academy library, and to exclude individuals who may have been working within the library but not in a librarian's role (like in human resources or information technology), researchers included only academic librarians in their analysis. To participate, respondents had to hold an advanced degree in library science or a field relevant to their position, depending on the subject focus of a particular librarian (for instance, a business subject librarian would have been included in the analysis if he or she held an MBA). As part of the survey, researchers asked demographic information like what type of employment an individual held within the academic library. Those who did not hold at least a master's degree in librarianship (or related field like archival management, or a field-related degree) were not included in the analysis. Researchers further controlled for specific employment statuses and demographic information in the analysis including factors like years of experience, minority identification, and tenure (for faculty status-granting 
institutions). Controlling for these variables allowed researchers to more accurately determine how gender affects salary negotiation practices.

Researchers sent the survey to the forty-four library directors, or appointed library contacts, who agreed to participate in the survey and used their suggestions to customize the survey to each library's organization and tenure processes. Given this customization (which included different questions about tenure and/or faculty status depending on the nature of the institution), the survey was approximately fifty-five questions long. Customization included using ranking categorizations or vocabulary that matched the institution, or skip logic associated with certain questions (such as if a respondent indicated that she had not negotiated her salary, the survey would skip questions about how much money she made from the negotiation).

After customizing the survey, researchers sent a link to the customized survey and asked participating library heads, directors, deans, or appointed library contacts to forward the survey link and invitation letter to each of his or her employees. The survey then weeded out participants who were not within the population that researchers were studying. To protect the integrity of the data, participants were required to affirm that they met certain criteria. These criteria were meant to narrow the focus of the study to professional librarians and included having an advanced degree as mentioned before, and being on a tenure track at the institutions that offered tenure to librarians. Approximately half of the sample were tenure-track librarians and the other half worked in institutions that did not offer tenure or its equivalent. Librarian participation was incentivized with an opportunity to enter a drawing for an iPad Air 2. The survey questions reported on in this article are included in appendix A.

Though researchers were unable to calculate a specific completion rate due to the fact that they did not know how many librarians were sent the survey through their library directors or the appointed library contacts, researchers collected 1,182 survey responses in total, and the current dataset reports on 1,153 of those. Ranges of responses per institution varied with the smallest institutional response at 10 and the largest at 101. Responses that were excluded from the dataset included librarians who indicated they did not work full-time hours, those who reported having only a bachelor's degree (with no other advanced degree in a relevant subject area), and any who refused to report their salaries. A total of 71.03 percent of the respondents were female, while 28.71 percent were male. Only 3 responders out of $1,153(.26 \%)$ chose not to answer the questions about their gender. These numbers can be compared to the 38.8 percent male and 61.2 percent female population of ARL libraries. ${ }^{29}$

The data were analyzed using a variety of methods. Two-way contingency tables and $\mathrm{t}$-tests were used to compare the negotiation rates between male and female librarians and between heads, deans, directors, and other librarians. Logistic regression analysis was used for a more detailed investigation of which variables contribute to the decision to negotiate salary; this method also allowed for control variables to arrive at more accurate conclusions. Finally, linear regression was used to determine how gender contributes to the success of salary negotiation, and a test of independence was done to show that the assumptions of these regression models were met.

Though researchers report a robust sample size for their findings, they do note a few limitations to this study. First is the already-mentioned inability to report a rate of return on the survey, since there was no way of knowing how many individuals were sent the survey in the first place-only the number of libraries that participated is reportable. Second is that the survey asks only about how often salary negotiations took place and the monetary returns of that negotiation. In some circumstances, individuals may have negotiated not for salary but for other benefits (like vacation, flexible schedules, or more robust retirement options). These other kinds of negotiations that may have 
taken place are not reported in the results; but, since the survey was part of a wider study regarding pay discrepancies, researchers chose to study monetary gains related solely to negotiation. Finally, although some literature shows that factors such as the gender of the negotiating administrator and the language used in job listings can affect negotiation practices, researchers did not study these phenomena specifically. This leaves the door open for further studies to corroborate and explain researchers' findings.

\section{Findings and Discussion}

\section{Finding 1: Female librarians negotiate less often than male librarians do.}

Using the sample of 1,025 librarians (which excluded data from heads, deans, and directors), researchers found that males do negotiate significantly more often than females, Pearson $\chi^{2}(1$, $\mathrm{N}=1025)=4.02, P=.04$ (please refer to table 1 ). To better understand the forces that contribute to an individual negotiating or not, researchers also analyzed the data using a logistic regression model. A basic specification with negotiation as the response variable and gender as the sole predictor yields a result similar to the previous two-way contingency table comparison, Pearson $\chi^{2}(1, \mathrm{~N}=1025)=4.28, P=.04$. Using logistic regression, however, researchers were able to control for other factors that predict negotiation. Controlling for minority status, allowing for interaction effects between gender and minority status, education, and years of previous experience, does not significantly alter the estimated effect of gender on negotiation. (For a breakdown of the other factors for which researchers controlled, see table 1.) The best estimate is that male librarians' odds of negotiating are 38 percent higher than female librarians with similar experience, education, and minority status. This estimate is statistically significant with $P=.04$.

\begin{tabular}{|c|c|c|c|}
\hline \multicolumn{4}{|c|}{$\begin{array}{c}\text { TABLE } 1 \\
\text { Demographics }\end{array}$} \\
\hline Gender & Count (\%) & Minority Status & Count (\%) \\
\hline Female & $819(71.22)$ & Minority & $159(13.83)$ \\
\hline Male & $331(28.78)$ & Nonminority & $991(86.17)$ \\
\hline Minority Breakdown & Count (\%) & Age & Count (\%) \\
\hline Asian & $47(29.56)$ & $20-29$ & $62(5.41)$ \\
\hline Black or African-American & $46(28.93)$ & $30-39$ & $316(27.60)$ \\
\hline Pacific Islander & $2(1.26)$ & $40-49$ & $301(26.29)$ \\
\hline American Indian or Native Alaskan & $3(1.89)$ & $50-59$ & $256(22.36)$ \\
\hline Hispanic & $39(24.53)$ & $60-69$ & $202(17.64)$ \\
\hline Other & $22(13.84)$ & $70-79$ & $8(0.70)$ \\
\hline Years of Experience & Count (\%) & Tenure & Count (\%) \\
\hline $0-9$ & $270(23.62)$ & Not Eligible & $42(6.98)$ \\
\hline $10-19$ & $372(32.55)$ & Tenure-track & $220(36.54)$ \\
\hline $20-29$ & $232(20.30)$ & Tenured & $340(56.48)$ \\
\hline $30-39$ & $185(16.19)$ & & \\
\hline $40+$ & $84(7.35)$ & & \\
\hline $\begin{array}{l}\text { * Responses of "NA" were not inclu } \\
\text { categories do not add up to the } 1,15\end{array}$ & in these tab & $\begin{array}{l}\text { which is why mo } \\
\text { ned in the paper. }\end{array}$ & the \\
\hline
\end{tabular}


These findings are significant in that they demonstrate different approaches to negotiation practices that significantly vary by gender. Studies by the Institute for Women's Policy Research comparing the ratio of women's and men's median annual earnings show that the ratio between men and women has not improved since 2007,30 a figure that may be affected by women not entering into negotiation at the same rate men do.

\section{Finding 2: Female librarians are less successful in their negotiations for higher pay than male librarians.}

Out of the 1,025 professional librarians (excluding heads, deans, and directors) used to analyze negotiation, 432 reported negotiating, and 427 of these who responded that they did negotiate also recorded a salary increase resulting from the negotiation. Using a two-sample t-test on the difference in mean salary increase, researchers find that males receive significantly more than females in their negotiations, $t(197)=2.26$, $P=.02$. While women reported an average increase of $\$ 2,273.92$ as a result of salary negotiation, the estimated average increase for men was $\$ 825.35$ more than the $\$ 2,273.92$ women received, $P=.01$.

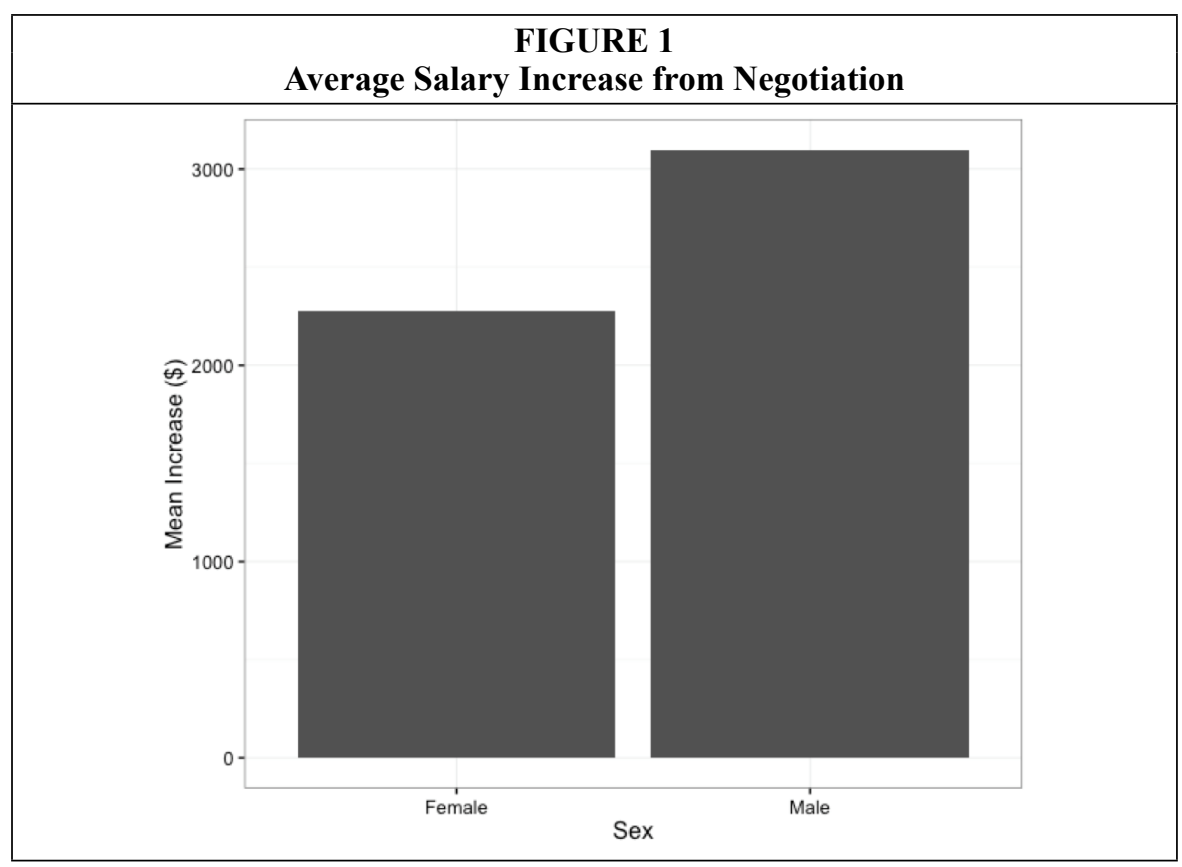

These numbers are important both in understanding the gender wage gap, but they are also important when looking at total earnings over the course of a career. Studies by the nonprofit research organization Catalyst, which studies women in the workplace, show that "the earning differences between women and men varies with age" and that younger women "are closer to pay equity" while "older women ...earn just $73.7 \%$ of men's [salary] for full time wage and salary." ${ }^{11}$ While the age wage gap could partially be explained by generational gender prejudices, it can also be explained by the fact that, over the course of a career, the more one earns, the more one's wages are compounded. So a man earning $\$ 825.35$ more starting a job may, decades in the future, be making significantly more than his female counterpart who did not receive as high a starting salary based on her negotiations. 


\section{Finding 3: Female library heads, deans, and directors negotiate more than female librarians do.}

For the bulk of the analysis, the 101 individuals who identified their roles as Associate, Assistant or Head Dean, or Director were excluded from analysis. This was done because the heads, deans, and directors differed significantly on the basis of observable characteristics from the overall sample, thus suggesting that there are also unobservable differences that researchers would be unable to account for in the analysis. However, comparing heads, deans, and directors to professional librarians resulted in some noteworthy conclusions.

Comparing the group of heads, deans, and directors to other librarians using a two-way contingency table analysis shows a significant difference in negotiation patterns, Pearson $\chi^{2}$ $(1, \mathrm{~N}=1,151)=6.25, P=.01$. Table 2 gives a breakdown by gender of the negotiation patterns for heads, deans, and directors vs. other librarians. The sample shows an interesting pattern in the negotiating habits of women in positions of power (heads, deans, directors) compared to others. Comparing the proportion of female directors who negotiate with other female librarians shows a significant difference between the two groups, Pearson $\chi^{2}(1, \mathrm{~N}=817)=9.55, P$ $=.002$. A comparison between female and male heads, deans, or directors, however, does not show a significant difference in negotiation, Pearson $\chi^{2}(1, \mathrm{~N}=100)=1.17, P=.28$. This lack of statistical significance could, perhaps, be attributed to the relatively small number of deans/ directors in the sample.

Readers might not consider this finding surprising, given the assumption that, the longer one works in any profession, the more likely that individual will be to negotiate his/her salary (as researchers also found true in academic libraries; see finding 4). However, researchers did not see a significant change in a man's propensity to engage in negotiations, as was observed for women. While women were 20 percent more likely to engage in negotiations when they achieved head, dean, or director status vs. when they were librarians, a man's likelihood to negotiate stayed relatively stable, with 47 percent of male librarians and male heads, deans, or directors indicating that they negotiated their salaries - a figure that remained constant independent of management level.

\begin{tabular}{|l|c|c|c|c|}
\hline \multicolumn{5}{|c|}{ TABLE 2 } \\
\hline & \multicolumn{2}{|c|}{ Head/Deans/Directors } & \multicolumn{2}{c|}{ Librarians } \\
\hline & Yes (\%) & No (\%) & Yes (\%) & No (\%) \\
\hline Female & $40(60.61)$ & $26(39.39)$ & $295(40.14)$ & $440(59.86)$ \\
\hline Male & $16(47.06)$ & $18(52.94)$ & $137(47.24)$ & $153(52.76)$ \\
\hline
\end{tabular}

\section{Finding 4: The longer one works in an academic library, the more likely that individual is to negotiate for a higher salary.}

In addition to the findings regarding gender and negotiation, researchers also found that the number of years an individual had worked before being hired into his or her current position was highly predictive of the choice to negotiate or not. Using logistic regression with negotiation as the response variable and controlling for gender and minority status, researchers estimated that each additional year of experience increased an individual's odds of negotiating by $3.8 \%, P<.001$. Figure 2 illustrates how the predicted probability of negotiating changed with years of experience, gender, and minority status (see figure 2). 


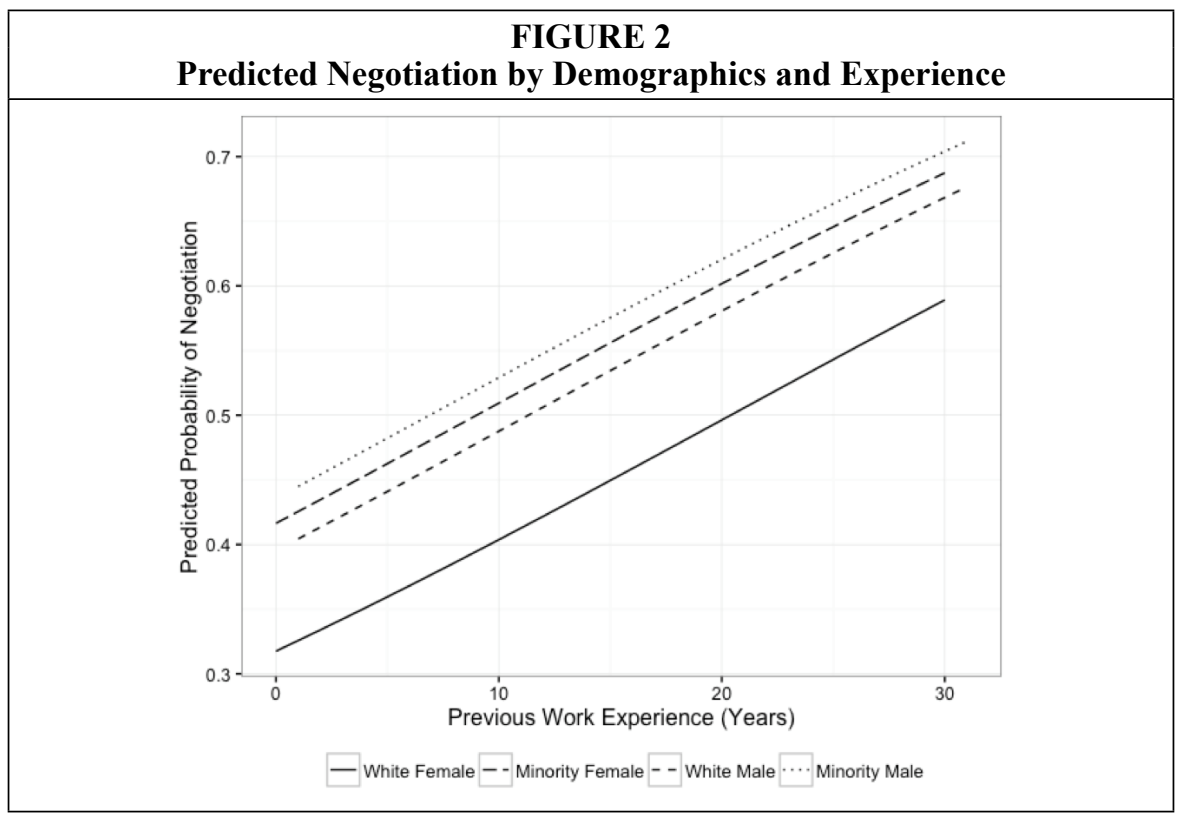

Such a propensity to enter into negotiations more willingly with more experience is hardly a surprising finding, but it is an important one in the context of salary compression - or the compounding of lower starting salaries over time. If an individual is unwilling to negotiate or receives a lower starting salary than a comparable individual who did negotiate over a lifetime of work, the losses are substantial. Recent research shows that salary compression is an issue in academic research libraries, though the rates do seem to be decreasing. ${ }^{32}$

Overall, these four findings together show an interesting disparity between male and female librarians and demonstrate how management positions affect a woman's likelihood of negotiating. While the authors concede that the findings of this study are part of a wider picture regarding pay discrepancies between men and women, they suggest more research needs to consider how negotiation patterns may be affecting pay disparities between men and women in academic libraries. Authors conclude that more research is needed to explain the results of this study within the wider realm of the gender wage gap.

\section{Recommendations for Further Research}

In a field with a keen awareness of social justice, ${ }^{33}$ these findings may be somewhat troubling for readers. There may be several explanations for the research results at hand, including the way job postings are written, the methods by which interviews are conducted, and implicit biases of those handling negotiations in academic libraries. One thing that is sure, though, is that this phenomenon should be more widely studied within the context of academic libraries and academia at large not only to corroborate the authors' findings but also to understand why female librarians negotiate less often and are less successful in their negotiations than men. It would also help to understand the disparity between female librarians and female heads, deans, or directors of libraries.

Questions that might be asked in these studies are the following: how do men and women differ when they approach the bargaining table in academic library settings? What prompts a man or a woman to bargain, or not to bargain, in the context of aca- 
demic libraries? How do managers react to negotiation requests and why? For instance, research suggests that women who approach pay negotiation in an "other-advocating" way (that is to say, framing the negotiation as a way for the applicant to help others on the team rather than help herself) leads to higher return rates. ${ }^{34}$ Because the authors' study reports on a smaller subsection of a wider study that considers gender and minority issues in salaries within academic libraries, the authors were unable to treat such multifaceted questions in this article but extend a call to other researchers to continue discussions started in this paper.

Overall, the authors of this article agree with Kennedy and Kray that reframing the discussion around pay discrepancy can be helpful in that restructuring the literature surrounding these issues can cultivate "a strong, positive social identity of women as astute negotiators." 35 Reframing the discussion on salary negotiations to showcase strengths rather than weaknesses may help chip away at the gender wage gap. Indeed, women may not be worse negotiators than men, and this study shows that they succeed if they are in more powerful management positions. Studying the ways that female library heads, deans, or directors negotiate vs. how female librarians negotiate might be a way of reframing such a discussion that would take into account how identities change as management opportunities for women within libraries grow.

\section{Conclusion: Practical Solutions to Solving the Problem}

At this point, administrators and prospective job applicants may wonder what practical solutions different parties may enact to address inequality in negotiation practices and achieve parity in pay between men and women in academic library settings. First, the authors argue that studies like the one this article reports on can work to bring awareness to issues of inequality in academic libraries and encourage both administrators and job applicants alike to reconsider propensities to engage in negotiation practices.

Another idea would put the onus on administrator and HR professionals to be clear in how salary offers are set and standardize the criteria used to make salary job offers using a number of elements like job experience, educational experience, technical abilities, emotional intelligence, and other relevant factors. The authors understand that, at different institutions, there are different salary-setting practices; but, if salaries were set in a transparent way, employees would have a greater understanding of their job offers. Furthermore, the language of the job post could offer clues to job seekers about whether negotiations are appropriate or not. Some institutions have tried to curb negotiation practices by offering the most competitive salary from the get-go, with no room to go higher in terms of monetary compensation. While the authors recognize that this could also be seen as a problematic approach if implicit bias colors the way salaries are set, it can also be considered a way of curbing the pay gap by not allowing salary negotiation at all-a practice that continues to benefit men more than women.

A final suggestion would be to better educate and inform female professionals in the field that negotiation is a significant part of the process with many jobs and that the most important time for negotiation is the time of hire. Indeed, after the applicant has started working, it is very difficult for most organizations-especially public ones - to renegotiate salaries. Professionalization courses through MLS degrees could help with this, but, overall, empowering women through educational means and continued scrutiny on gender bias are important factors in lessening the perpetual pay gap between men and women in the field. 


\section{APPENDIX A. Salary Differences Survey}

*Note: Only questions reported on in this article are shown here. The beginning of the survey asked demographic and job-ranking questions (for instance, a respondent would indicate whether he or she was a library director, subject librarian, or other employee type at the beginning of the survey).

How many years total have you worked at your current institution?

How many years of related work experience did you have before you began working at your current library? (This includes direct work experience in a library position or indirect work in a position that is highly relevant to the job. For example, a science subject librarian may have worked as a researcher.)

Out of the total years of related work experience reported in the last question, how many were in a library position?

When you were initially hired at your current institution, did you attempt to negotiate a higher salary?

How much did your beginning salary increase as a result of your negotiations?

If you were to accept a position at another library, would you try to negotiate for higher salary?

\section{Notes}

1. Barbara B. Moran, Elisabeth Leonard, and Jessica Zellers, "Women Administrators in Academic Libraries: Three Decades of Change," Library Trends 58, no. 2 (2009): 215.

2. Ibid., 222.

3. Marta Deyrup, "Academic Library Leadership, Second-Wave Feminism and Twenty-First Century Humanism: Reflections on a Changing Profession," in Leadership in Academic Libraries Today: Connecting Theory to Practice, eds. Brad Eden and Jody Condit Fagan (Lanham, Md.: Rowman \& Littlefield, 2014), 91-141.

4. Susan D. Phillips and Anne R. Imhoff, "Women and Career Development: A Decade of Research," Annual Review of Psychology 48, no. 1 (1997): 31.

5. Martha Kyrillidou and Shaneka Morris, ARL Annual Salary Survey 2014-2015 (Washington, D.C.: Association of Research Libraries, 2015), 15.

6. Ephraim R. McLean, Stanley J. Smits, and John R. Tanner, "The Importance of Salary on Job and Career Attitudes of Information Systems Professionals," Information \& Management 30, no. 6 (1996): 291-99, doi:10.1016/S0378-7206(96)01059-2; Terry Cottrell, "Moving On: Salaries and Managing Turnover," Bottom Line: Managing Library Finances 24, no. 3 (2011): 187-91.

7. Joan McConkey, Susan Anthes, Ellen Robertson, and Barbara Bintliff, "Salary Equity: A Case Study," College \& Research Libraries 54, no. 1 (1993): 33-41.

8. Mary Ann Mason, "Still Earning Less," Chronicle of Higher Education (January 13, 2010). Available online at https://www.chronicle.com/article/Still-Earning-Less/63482 [accessed 14 February 2018].

9. Ulrike Muench, Jody Sindelar, Susan H Busch, and Peter I. Buerhaus, "Salary Differences between Male and Female Registered Nurses in the United States," Journal of the American Medical Association 331, no. 12 (2015): 1266.

10. Jessica A. Kennedy, Laura J. Kray, and Gillian Ku, "A Social-Cognitive Approach to Understanding Gender Differences in Negotiator Ethics: The Role of Moral Identity," Organizational Behavior and Human Decision Processes 138 (2017): 28-44, doi:10.1016/j.obhdp.2016.11.003.

11. J. Dennehy, Competition, Gender and Management: Beyond Winning and Losing (London, U.K.: 
Palgrave Macmillan, 2012), 108, available online at ProQuest ebrary [accessed 14 April 2017].

12. Linda Babcock and Sarah Laschever, Women Don't Ask: Negotiation and the Gender Divide (Princeton, N.J.: Princeton University Press, 2003), 1.

13. Ibid., 2.

14. Cynthia Kay Stevens, Anna G. Bavetta, and Marilyn E. Gist, "Gender Differences in the Acquisition of Salary Negotiation Skills: The Role of Goals, Self-Efficacy, and Perceived Control," Journal of Applied Psychology 78, no. 5 (1993): 732.

15. Barry Gerhart and Sara Rynes, "Determinants and Consequences of Salary Negotiations by Male and Female MBA Graduates," Journal of Applied Psychology 76, no. 2 (1991): 256.

16. Claire Etaugh and Judith Bridges, Women's Lives: A Topical Approach (Allyn \& Bacon, Boston, 2008), 313.

17. Hannah Riley Bowles, Linda Babcock, and Lei Lai, "Social Incentives for Gender Differences in the Propensity to Initiate Negotiations: Sometimes It Does Hurt to Ask," Organizational Behavior and Human Decision Processes 103, no. 1 (2007): 84-103.

18. Christine L. Exley, Muriel Niederle, and Lise Vesterlund, "Knowing When to Ask: The Cost of Leaning In" (NBER Working Paper No. 22961, National Bureau of Economic Research, December 2016), available online at www.nber.org/papers/w22961 [accessed 7 March 2017].

19. Kennedy, Kray, and Ku. "A Social-Cognitive Approach to Understanding Gender Differences," 40.

20. Aurora Garca-Gallego, Nikolaos Georgantzs, and Ainhoa Jaramillo-Gutirrez, "Gender Differences in Ultimatum Games: Despite Rather Than Due to Risk Attitudes," Journal of Economic Behavior E Organization 83, no. 1 (2012): 46.

21. Jessica A. Kennedy and Laura J. Kray, "A Pawn in Someone Else's Game? The Cognitive, Motivational, and Paradigmatic Barriers to Women's Excelling in Negotiation," Research in Organizational Behavior 35 (2015): 7.

22. Karin Hederos Eriksson and Anna Sandberg, "Gender Differences in Initiation of Negotiation: Does the Gender of the Negotiation Counterpart Matter?" Negotiation Journal 28, no. 4 (2012): 407-28.

23. Andreas Leibbrandt and John A. List, “Do Women Avoid Salary Negotiations? Evidence from a Large-Scale Natural Field Experiment," Management Science 61, no. 9 (2015): 2017.

24. Dacina Crina Petrescu, "What Triggers a Negotiation: An Economic or a Social Goal?" Ecoforum Journal 6, no. 1 (2017): 1-7.

25. Emily T. Amanatullah and Michael W. Morris, “Negotiating Gender Roles: Gender Differences in Assertive Negotiating Are Mediated by Women's Fear of Backlash and Attenuated When Negotiating on Behalf of Others," Journal of Personality and Social Psychology 98, no. 2 (2010): 256-67.

26. Mary Hogue, Janice D. Yoder, and Steven B. Singleton, “The Gender Wage Gap: An Explanation of Men's Elevated Wage Entitlement," Sex Roles 56 (2007): 577.

27. Patrick Gavan O'Shea and David F. Bush, "Negotiation for Starting Salary: Antecedents and Outcomes among Recent College Graduates," Journal of Business and Psychology 16, no. 3 (2002): 378.

28. Simone Moran and Ilana Ritov, "Experience in Integrative Negotiations: What Needs to Be Learned?" Journal of Experimental Social Psychology 43, no. 1 (2007): 83-84.

29. Kyrillidou and Morris, ARL Annual Salary Survey 2014-2015, 14.

30. Ariane Hegewisch and Asha DuMontier, "The Gender Wage Gap: 2015: Annual Earnings Differences by Gender, Race, and Ethnicity," Institution for Women's Policy Research (2016).

31. "Women's Earnings and Income" Catalyst: Workplaces that Work for Women, available online at http://www.catalyst.org/knowledge/womens-earnings-and-income [accessed 26 February 2018]

32. Scott Seaman, "Salary Compression: A Time-Series Ratio Analysis of ARL Position Classifications," portal: Libraries and the Academy 7, no. 1 (2007): 7-24, available online at https://muse. jhu.edu/ [accessed 14 April 2017].

33. Myrna Morales, Em Claire Knowles, and Chris Bourg, “Diversity, Social Justice, and the Future of Libraries," portal: Libraries and the Academy 14, no. 3 (2014): 439-51; Risa Maureen Lumley, "The Academic Library and Social Justice: A Q-Study of Librarian Attitudes" (EdD dissertation, CSUSB, 2016), 1-156; "Core Values of Librarianship," American Library Association (ALA), available online at www.ala.org.erl.lib.byu.edu/aboutala/governance/policymanual/ updatedpolicymanual/section2/40corevalues [accessed 13 April 2017].

34. Amanatullah and Morris, "Negotiating Gender Roles," 257.

35. Kennedy and Kray, "A Pawn in Someone Else's Game?" 23. 